Dept of Theriogenology,

Fac. Vet. Med., Suez Canal University

Head of Dept. Prof. Dr. S.M. Sharawy.

\title{
CLINICAL, HEMATOLOGICAL AND HISTOPATHOLOGICAL STUDIES ON ABORTION AND STILLBIRTH IN CATTLE AND BUFFALOES (With 8 Tables and 12Figures)
}

\section{By}

S.A. ATALLAH; S.M. ALY* and O.A. ABD-ALLAH**

*: Dept of Pathology, ** and Clinical Pathology,

Yac. Vet. Med, Suez Cana!

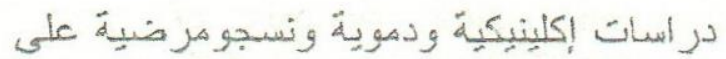

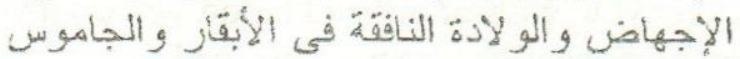

$$
\begin{aligned}
& \text { سيد }
\end{aligned}
$$

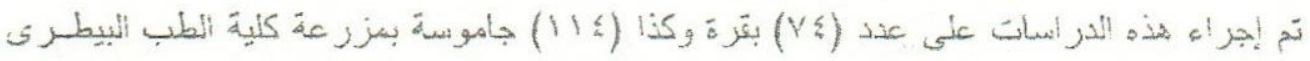

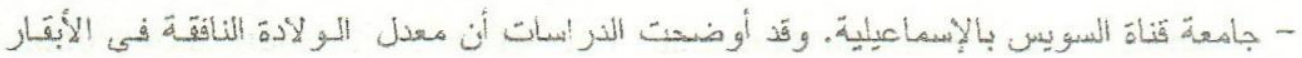

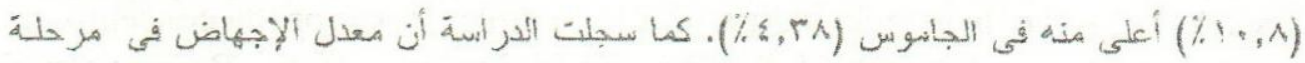

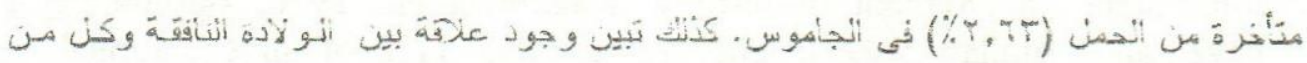

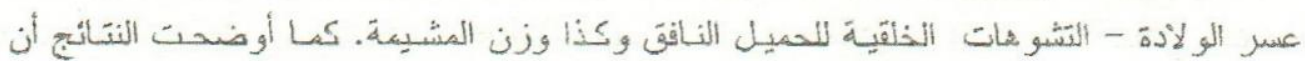

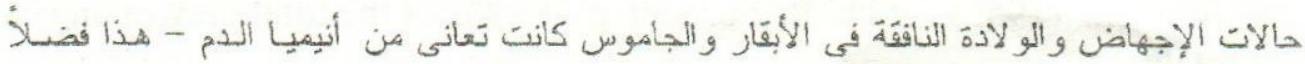

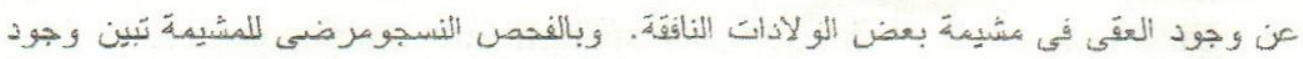

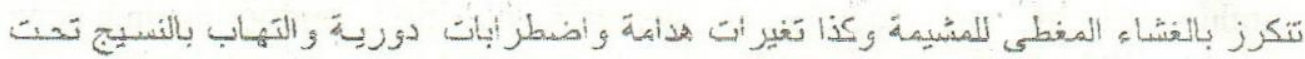

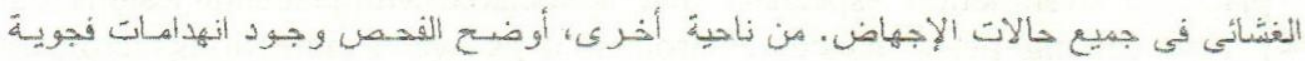

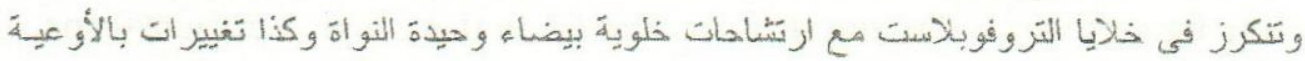

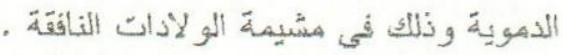




\section{SUMMARY}

In this study, 74 cows and 114 buffaloes were followed up during pregnancy and peripartum period at the Animal Farm, Faculty of Veterinary Medicine, Suez Canal University, Ismailia, EGYPT. Stillbirth rate was higher in cattle $(10.81 \%)$ than that of buffaloes $(4.38 \%)$. Late abortion accounted for $2.63 \%$ in buffaloes. An association between calving performance, anomalus fetus, weight of the placenta and stillbirth was found. Similarly, in both cattle and buffaloes, anemia was reported among the dams that showed abortion or stillbirth. In the mean time, meconium staining of the placenta was noticed in some stillbirths in buffaloes. Histopathologically, the placentae of the aborted animals revealed focal to diffuse necrosis in the epithelial covering along with degenerative change, circulatory disturbances and inflammatory reaction in the subepithelial tissue. The placental picture in stillbirth cases revealed vacuolar degeneration and/or necrosis of most trophoblasts with mononuclear leukocytic infiltration and blood vessels involvement. Chronic proliferative form of placentitis was not observed.

Key words: Cattle - Buffaloes - Abortion - Clinical picture

\section{INTRODUCTION}

Abortion and stillbirth constitute one of the major sources of economic setback to the livestock industry due to direct losses of the conceptus and consequent impairement of fertility (Kaikini et al., 1976; Barnouin et al., 1992 and Atallah 1993). They represented 31\% of all gestational and periparturient reproductive troubles in buffaloes (Atallah 1993). According to Withers (1952), stillbirth accounted $56.4 \%$ of the total preweaning calf mortality.

Unfortunately as abortion and stillbirth are multietiological problems influenced by risk factors as genetics, nutrition, endocrine imbalance, placental dysfunction especially that associated with placental lesions, dam parity, calving performance, enviromental as well as infectious factors and the figure remains obscure (Roberts, 1986). In that sense, a definite diagnosis for the exact cause in such problems is rather difficult and could not be achieved in about $25 \%$ of the cases even if extensive laboratory examinations are carefully conducted (Klingborg, 1987; Thurmond et al., 1989).

So, the present study aimed, first to determine incidence of abortion and stillbirth in cattle and buffaloes in relation to some enviromental and 
managemental risk factors, secondly to focus on the hematological picture asssociated with such problems and thirdly to investiagte the gross as well as histopathological picture of the placenta associated with abortion or stillbirth compared to that of normal calvings.

\section{MATERIAL and METHODS}

\section{(A) Animals:}

This work was carried out on 74 crossbred (Friesian $\mathrm{X}$ native ) cows and 114 buffalo cows during the period from August 1995 till the end of July 1996. All animals were reared in the animal farm station, Faculty of Veterinary Medicine, Suez Canal University, Ismailia-Egypt. All animals were kept under veterinary supervision and vaccinated against some infectious diseases e.g. cattle plague, black leg, foot and mouth disease and were routinely treated against both internal and external parasites. Also, the herd proved to be free from Brucellosis, Tuberclosis through a yearly testing programme.

(B) The study protocol :

(I) Follow up and collection of data:

During this study, all cows and female buffaloes in the herd were fo..'owed up during pregnancy and periparturient period. A". cases of abortion and stillbirth were recorded, also data concerning dam parity, stage of pregnancy in relation to time of abortion or stillbirth, any signs of illness prior to such problems were collected. The abortus or stillborn calf was noted for sex, viability, body weight as well as any congenital anomalies.

(II) Blood sampling for hematological study:

In heparinized vacutainer tubes, blood samples were collected immediately after abortion or stillbirth. The total erythrocytic and leukocytic counts, the packed cell volume, hemoglobin concentration, mean corpscular value (MCV by FL), mean corpscular hemoglobin concentration ( $\mathrm{MCHC} \%$ ) and mean corpscular hemoglobin ( $\mathrm{MCH}$ by $\mathrm{pg}$ ) were estimated and calculated as described by Jain (1986).

(III) collection and examination of the placentae :

(i) Macroscopic Examination :Immediately after expulsion, foetal membranes were collected and carried to the laboratory for detailed examination as follow :- Each placenta was cleaned, weighed and examined grossly for presence of any lesions as discolouration, 
edema, hemorrhage and necrosis of the cotyledons. The cotyledons were counted and the diameter of each one was measured. The cotyledons were classified as large (10 $\mathrm{cm}$ and above), medium (less than $10 \mathrm{~cm}$ and above $5 \mathrm{~cm}$ ) and small (less than $5 \mathrm{~cm}$ ).

(ii) Histopathological examination :- A tissue specimen from each placenta was collected and immediately fixed in neutral buffered formalin $10 \%$ for $48 \mathrm{~h}$. The fixed specimens were then dehydrated using ascending grades of ethanol, cleared in two changes of xylene, embeded in paraffin wax, sectioned at $5 \mu$ and stained with routine hematoxylin and eosin. Special stains for bacteria (Brown and Brenn) and fungi (PAS) were also used (Luna 1968).

N.B. The number of the blood samples and placentae for the diseased as well as the control group used in the clinical, gross and the histopathological examination are presented in in table (1).

(IV) Statistical analysis:

The obtained data were statistically analysed according to Snedecor and Cochran (1967).

\section{RESULTS}

(I) Incidence of abortion and stillbirth in relation to some etiological factors :

Data about monthwise distribution, incidence as well as seasonal pattern of abortion and stillbirth in cattle and buffaloes are presented in tables (2) \& (3). A higher rate of stillbirth (10.81\%) was found in cattle compared to low incidence $(4.38 \%)$ in buffaloes. While late abortion accounted for $2.63 \%$ in buffaloes. With regard to seasonal pattern for calving, abortion as well as stillbirth tables (2) \& (3) showed that autumn $(35.13 \%)$ and spring $(31.08 \%)$ as most calving seasons for cattle compared to autumn $(38.59 \%)$ and winter $(28.94 \%)$ in buffaloes. The figure showed also a higher incidence of stillbirth in summer, however, the rate of late abortion was nearly equal during winter $(6.66 \%)$ and summer $(5.55 \%)$.

As shown in tables (4) \& (5), a higher incidence of stillbirth (7.4\%) was found among second parity buffalo-dams compared to an equal rate between the first and second party dams of cattle. In that sense, $(37.57 \%)$ of stillbirths. in cattle was associated with difficult calvings compared to $20 \%$ only in buffaloes. However, about $33.3 \%$ of late abortion in buffaloes required an obstetrical assistance. 
With respect to the anatomical status of stillborn calves our data showed that $(37.5 \%)$ of stillbirths in cattle were anomalus compared to $20 \%$ in buffaloes. (Figs $1 \& 2$ ).

\section{(II) Hematological Picture :-}

With regard to late abortion in buffaloes, the hematological picture was macrocytic normochromic anemia (megaloblastic) as noted in table (7).

As shown in table (8), stillbirth in cattle was associated with macrocytic hypochromic anemia and leukopenia. In buffaloes, the corresponding figure was microcytic hypochromic anemia and leukocytosis.

\section{(III) Gross morphology and histopathology of the placentae :}

(i) Macroscopic examination of fetal membrances: In buffaloes $20 \%$ of the placentae associated with stillbirth showed meconium staining and yellowish discolouration of the cotyledons. For the control group in cattle and buffaloes, the fetal membranes had cotyledons of grey to brown colour and villi of uniform and smooth surfaces (Figs. 3\&4).

Our results showed a marked difference in the weight of placentae between stillbirths and normal calvings (table 6)

(ii) Histopathological examination of the placentae : Histopathological examination of the placentae associated with normal calving in cattle and buffaloes showed vacuolar degeneration in the epithelium covering (trophoblast) of the chorionic villi, other area exhibited focal to diffuse epithelial necrosis and/or desquamation. The subepithelial tissue was highly vascular and revealed mild congestion, edema, and hemorrhages. The mesenchymal cells of interstitium varied in shape and size. These cells floated in a faintly basophilic fibrillar edematous matrix. The blood vessels contained intact erythrocytes and showed hyalinized wall and/or sloughed endothelium. The spontanously dropped placenta of some cows were suffered focal placentitis where the placental tissue exhibited severe congestion and focal mononuclear leukocytic infiltration. (Fig.5 \& 6).

For abortion, the histopathological figure in buffaloes revealed focal to diffuse necrosis in the epithelial covering along with infiltration of the necrotic areas by mononuclear leukocytes, mainly lymphocytes, macrophages and giant cells (Fig. 7). The subepithelial tissue exhibited degenerative changes (mainly hyaline degeneration), circulatory disturbances (edema and hemorrhages) and inflammatory reactions (congestion and mononuclear leukocytic infiltration) (Fig. 8). The 
placental vessels showed degenerated and necrotic endothelium along with perivascular fibrosis (Fig.9).

From the histopathological examination of the placentae associated with stillbirth in cattle and buffaloes, it was evident that the majority of trophoblasts were necrotic and showed pyknotic or karyolytic nuclei (Fig. 10). Some cells were ruptured while the rest exhibited vacuolar degneration. Focal infiltration of mononuclear and giant cells in the necrotic epithelium of the chorionic villi was obvious. Extensive edema and massive hemorrhage in the placental tissue were noticed. The placental blood vessels especially in buffaloes showed vaculated and hyalinized wall, necrotic endothelium, thrombosis, congestion and perivascular fibrosis (Fig. 11). Other placental vessels were ruptured. Focal infiltration of mononuclear and giant cells were evident in the placenta of most cases. Such changes were observed among 9 placentae associated with stillbirth ( 3 cattle and 6 buffaloes) .

The histopathological sections of placental tissues of most cows and few buffaloes from different groups even in some cases of the control group, after staining with Brown and Broenn method for bacteria, revealed the presence of both Gram positive (Cocci, diplococci and bacilli) and Gram negative (Bacilli \& Coccobacilli) bacteria (Fig. 12) while after staining with PAS stain for fungi did not reveal the presence of any mycotic hyphae or spores.

\section{DISCUSSION}

(I) Incidence of abortion and stillbirth in relation to some etiological factors :

In respect to the incidence of stillbirth in cattle, our data agreed those of Szenci et al., (1988) who indicated an incidence that ranged from 7.4 to $8.6 \%$. By Contrast such results were higher than those of Lindstrom and Vilva (1977) who reported an incidence of 3\%.On the other hand, our results indicated that stillbirth rate in buffaloes was much lower $(3.38 \%)$ than that of cattle $(10.81 \%)$, that came in support to those of Kaikini et al., (1976); Sharma et al., (1983) and Atallah (1983). By the way, the rate of late abortion in the present study came in close agreement with those of Surinder ef al., (1986), but much lower than that previous data of Atallah (1993). 
Any how, the discrepancies in the incidence of pathological termimation of pregnancy (Aborton or stillbirth) between cattle and buffoloes or even within the same species could be attributed to variations in parity, environmental and/or managemental circumstances as well as differences between species (Philipsson 1976 and Roberts 1986).

Concerning the seasonal pattern of abortion and stillbirth, the high rate of stillbirth in summer agreed those of Auran (1972), a high and equal rate of late abortion was noted in winter and summer which is partially in line with those of Tomar and Verma (1987) who stated a high rate of abortion in summer followed by winter.

In that sense, although we are unable to interpret the high rate of abortion in winter, the high risk of stillbirth during summer could be explained as despite a lot of green fodder (elephant grasses) was offered to the herd of this study during such season, perhaps nutritional disturbances, thyroid dysfunction during extremly hot summer or infection may have been involved. Moreover, the obtained results violate previous data of Atallah (1993) who found the majority of stillbirths during autumn and winter, so we are in support to the statement that no clear pattern between the season and the risk of fetal death or premature birth (Philipsson 1976).

With regard to the relationship between dam parity and abortion or stillbirth, we could say although the rate of abortion and stillbirth seem to be more or less high among the first and second parities, it is difficult to claim a definite association between parity and such troubles, perhaps due to the relative small size of the material in the study. Any how, our data came in support to those of Tomar and Verma (1987) and Atallah (1993) but in contrast to Philipsson (1976).

Concerning the association between calving performance and perinatal mortality, our data were in support to those of Philipsson (1976) who claimed that about 40 to $60 \%$ of all dead calves were born with difficulty.

Regarding the associaton between stillbirth and the congenital abnormalities of the fetus, our results were in support to such claim mentioned by Bellews et al., (1987) and Mee (1991b).

(II) Hematological picture : The association between anemia and stillbirth in the obtained results may agree with those of Whitfield (1995) who claimed that anemia remains a major contributing factor for perinatal mortallity. Moreover, transitory leukopenia is the common initial response to inflammatory disease in cow (Anderson 1970). However leukocytosis 
could be a result of various infectious and non infectious diseases processes (Maile 1982).

On the other hand, our results showed a megaloblastic anemia in buffaloes did late abortion that came in support to Shemanchuk, et al., (1960) who stated that the anemic conditions of the cows was responsible for abortions. In that sense megaloblastic anemia could be a consequence to some nutritional disturbances.

(III) Gross morphology and histopathology of the placentae :

(I) Macroscopic examination of foetal membrances:

The obtained results in our study that $20 \%$ of stillbirths in buffaloes was assoeiated with meconium staining may reflect fetal hypoxia (Walker 1954). In that sense, fetal hypoxia could be attributed to the anemic condition of such animals that observed in the haematological picture of our data.

Moreover, the marked decrease $(\mathrm{P}<0.05)$ in the weight of the placentae associated with stillbirth in cattle may reflect placental insufficiency as a risk factor for such reproductive troubles.

On the other hand, our results showed no signs of illness prior to abortion or stillbirth in cattle and buffaloes. Similarly no association between expulsion time of placenta and stillbirth. Such data disagreed those of Mee (1991a) who claimed an association between stillbirth and premature expulsion of placenta.

(ii) Histopathological examination of the placentae:

The histopathological changes observed in the placentae of aborted and stillbirth cases in our study were summarized in degenerative and necrotic changes along with circulatory and inflammatory reactions. The observable wide spread necrosis severe or at least impair the placental connection between the dam and fetus resulted in abortion, nevertheless, in some cases the reaction was milder so that the calf might be delivered as a stillborn calf.

The vascular involvement of the placentae of aborted and stillbirth cases was commonly noticed in buffaloes, they include degenerated and necrotic endothelium, thrombosis, vaculated and hyalinized wall and perivascular fibrosis. The vascular changes impair the circulation to the placenta and fetus and consequently resulted in a placental degeneration and/or necrosis and fetal death. That may provide an explantion for the absence of gross lesion in the placentae associated with abortion or even some cases of stillbirth (Jubb et al.1993). 
As our data showed that abortion and stillbirth were not preceded or assocciated with any signs of illness that may incriminate the chronic placental involvement in the form of localized perivascular fibrosis and giant cells infiltration and anemia as a risk factors for such troubles. Such data violate those of Jubb et al. (1993) who stated that abortion and stillbirth may be an incidental feature of many acute illness not fundamently localized in the genital tract including non infectious diseases. On the other hand, the histopathological figure that a chronic proliferative form of palcentitis with diffuse and sparsely arranged fibrosis along with marked inflammatory edema which aided by thickening to the tips of the chorionic villi and ties the chorion to the endometrium, did not appear in the present study, could provide an explantion for the question, why no association between placental retention and abortion or stillbirth was observed.

By the way, histopathological examination of the placental tissue in the present work showed presence of both Gram positive and Gram negative bacteria in the control as well as the diseased groups and associated with focal placentitis of most cows and few buffaloes. Any how, such bacteria could be a secondary invador or normal inhabitant to the genital tract and placenta. These findings may agreed Jubb et al.(1993) who stated that many different species of bacteria as coliform, streptococci, staphylococci and corynebacterium may be isolated from abortuses but their role is usually uncertain.

\section{CONCLUSION}

As abortion and stillbirth were associated with anemia, that could be an urgent call to provide more attention for feeding and health management.

As anomalus fetus accounted for $37.5 \%$ and $20 \%$ of stillbirths in cattle and buffaloes respectively, all notes regarding the genetic indices used in selection of dairy cows and sires, breeding programs as well as culling practices should be cosidered.

\section{REFERENCES}

Anderson, H.A. (1970): Evaluation of leukopenia in cattle. J. Amer. Vet. Med. Ass., 152: 858 - 865. 
Atallah, S.A. (1993): Some studies on reproductive disorders during pregnancy and puerperium in buffaloes. Ph.D. Thesis, Suez Canal University.

Auran, T. (1972): Factors affecting the frequency of stillbirths in Norwegian cattle. Acta Agric. Scand., 22 : 178-182.

Barnouin, J.; Chalus, T. and Lescourret, F. (1992): Increased perinatal French dairy calf mortality associated with fresh rape in the prepartum diet. Prev. Vet. Med. $12: 111-120$.

Bellows, R.A.; Patterson, D.J.; Burfening, P.J. and Phelps, D.A. (1987):

Occurrence of neonatal and postnatal mortality in range beef cattle. 11.Factors contributing to calf death. Theriogenology, $28: 573$ 586.

Jain, N.C. (1986): Schalm's Veterinary Hematology 6th Ed. lea and Febiger Philadelphia U.S.A.

Jubb K.V.; Kennedy P.C and Palmer N .(1993): Pathology of Domestic Animals, 4thEd. Academic press, Inc., Cal. U.S.A.

Kaikini, A.S.; Kadu, M.S.; Bhandari, R.M. and Belorker, P.M. (1976):

Incidence of normal and pathological termination of pregnancy in dairy animals. Indian J. Anim. Sci. 46: 19-22.

Klingborg, D. (1987): Normal reproductive parameters in large "Californiastyle" dairies. Vet. Clin. N. Am., $3: 483-499$.

Lindstrom, U.B. and Vilva, $V$. (1977): Frequency of stillborn calves and its association with production traits in Finnish cattle breeds. ZTierzuchtg . Zuchtgsbiol., 94:27-43.

Luna, L.G. (1968): Manual of histopathologic staining methods of the armed institute of pathology. 3rd Ed., Mc Graw. Hill Inc., New York. $258 \mathrm{pp}$.

Maile, J.B. (1982): Laboratory medicine hematology. 6th Ed. C.V. Mosby, St. louis.

Mee, J.F. (1991a): Premature expulsion of the placenta and bovine perinatal mortality. Vet Rec. 128, 521-523.

Mee, J. F. (1991b): Perinatal calf mortality, recent findings-Irish Veterinary Journal, $44: 80-83$.

Philipsson, J. (1976): Studies on calving difficulty, stillbirth and associated factors in Swedish cattle breeds, ph.D. thesis. The Swedish Univ. of Agriculture, uppsala-Sweden..

Roberts, S.J. (1986): Veterinary Obstetrics and Genital Diseases. 3rd Ed., published by the author, Vermont. 
Sharma, M.C.; Pathak, N.N.; Verma, R.P.; Hunng, N.N.; Lien, N.H.; An, D.T.; Mai, H.V. and VUC, N.V. (1983): Epidemiological study on reproductive disorders of Murrah buffaloes bred in Vietnam. Indian vet.J., $68: 83-86$.

Shemanchuk, J.A.; Haufe, W.O. and Thompson, C.O.M. (1960): Anaemia in range cattle heavily infested with short nosed sucking louse, Haematopinus eury sternus (NITZ), Anoplura; Haematopinidae. Can. J. Comp. Medicine, 24:158. Cited by Norton, J.H. (1987): Studies on bovine abortion on the Atherton Tableland, Ph.D. Thesis, James Cook University, Townsville, Queensland.

Snedecor, G.W. and Cochran, W.G.(1967): Statistical methods. 6th Ed. Iowa state Univ. Press. Ames, U.S.A.

Surinder, S.; Bhalaru, S.S. and Tiwana, M.S. (1986): Effect of body condition at calving on calving disorders in buffaloes. Indian Vet. J ., 63: 851-853.

Szenic, O.; Taverne, M.A.M.; Bakonyi, S. and Erododi, E. (1988):

Comparison between pre- and postnatal acid base status of calves and their perinatal mortality - The veterinary quarterly, $10: 140$ 145.

Thurmond, M.C.; Picanso, J.P. and Jameson, C. (1989): Descriptive epidemiology of abortion on a California dairy. Proceedings of the 68 th Annual meeting of the conference of research workers in Animal diseases- 16 November 1987, Chicago II. Abstract No. 105.

Tomar, S.S. and Verma, G.S. (1987): Factors affecting prenatal losses in Murrah buffaloes. Indian Vet. J., 64 : 483-493.

Walker, J. (1954): Foetal anoxia. J. Obstet. Gynaecol. Brit. Empire. 61:162. Cited by Schuijt, G. (1992): Aspecten van Obstetrische Perinatologie Bij Runderen. Thesis, Utrecht.

Whitfield, C.R. (1995): Dewhurst's Textbook of Obstetrics and Gynaecology for postgraduates.5th Edition, Blackwell Science, 228-250.

Withers, F.W. (1952): Mortality rates and disease incidence in calves in relation to feeding management and other environmental factors. British Vet. J. 108 : 315-328. 
Table (1):

Fetal membranes and blood samples collected from cattle and

buffaloes with abortion, stillbirth and their control.

\begin{tabular}{|c|c|c|c|c|c|c|c|c|}
\hline $\begin{array}{c}\text { Type of } \\
\text { sample }\end{array}$ & \multicolumn{4}{|c|}{ Cattle } & \multicolumn{4}{c|}{ Buffalo } \\
\cline { 2 - 9 } & $\begin{array}{c}\text { late } \\
\text { abortion }\end{array}$ & control & stillbirth & control & $\begin{array}{c}\text { late } \\
\text { abortion }\end{array}$ & control & stillbirth & control \\
\hline$*$ *.Blood & $\cdots--$ & $\cdots--$ & 8 & 10 & 3 & 6 & 5 & 10 \\
\hline **Placentae & $\cdots--$ & $\cdots--$ & 8 & 10 & 3 & $\cdots$ & 5 & 10 \\
\hline
\end{tabular}

*. Heparinized blood to demonstrate blood picture

**. Placentae to be examined grossly and histopathologically

Table (2):

Monthwise distribution of normal calvings, abortion and stillbirth in cattle and buffaloes during 1995/96

\begin{tabular}{|c|c|c|c|c|c|c|c|c|}
\hline \multirow{2}{*}{$\begin{array}{l}\text { Month of } \\
\text { the year }\end{array}$} & \multicolumn{4}{|c|}{ Cattle } & \multicolumn{4}{|c|}{ Buffalo } \\
\hline & $\begin{array}{l}\text { Normal } \\
\text { calvings }\end{array}$ & Abortion & Stillbirth & Total & $\begin{array}{l}\text { Normal } \\
\text { calvings }\end{array}$ & Abortion & Stillbirth & Total \\
\hline August/95 & $\cdots+\cdots$ & $\cdots+\cdots$ & $\cdots$ & $\cdots$ & 2 & $\cdots$ & 1 & 3 \\
\hline September/95 & 17 & ...... & 4 & 21 & 24 & ....... & 1 & 25 \\
\hline October/95 & 2 & $\cdots+\cdots$ & -..--. & 2 & 9 & -..... & 1 & 10 \\
\hline November/95 & 2 & $\cdots+\cdots$ & 1 & 3 & 9 & ....... & -....... & 9 \\
\hline December/95 & 8 & ....... & (n........ & 8 & 11 & ....... & (n...... & 11 \\
\hline January/96 & 3 & $\ldots . . .$. & ........ & 3 & 10 & 1 & (n...... & 11 \\
\hline February/96 & 4 & ...... & $\cdots$ & 4 & 9 & 1 & 1 & 11 \\
\hline March/96 & 7 & -...... & $\cdots$ & 7 & 10 & (...... & -......- & 10 \\
\hline April/96 & 10 & -...... & -....- & 10 & 3 & -..... & ........ & 3 \\
\hline May/96 & 6 & ....... & (n...... & 6 & 6 & ...... & (........ & 6 \\
\hline June/96 & 6 & ......... & 3 & 9 & 8 & 1 & 1 & 10 \\
\hline July/96 & 1 & --..-. & -...... & 1 & 5 & ...... & -....... & 5 \\
\hline $\begin{array}{c}\text { Total } \\
\%\end{array}$ & $\begin{array}{c}66 \\
89.18\end{array}$ & $\ldots \ldots$ & $\begin{array}{c}8 \\
10.81\end{array}$ & 74 & $\begin{array}{c}106 \\
29.98\end{array}$ & $\begin{array}{c}3 \\
2.63\end{array}$ & $\begin{array}{c}5 \\
4.38\end{array}$ & 114 \\
\hline
\end{tabular}


Table (3): Seasonal distribution of abortion and stillbirth in cattle and buffaloes during 95/96.

\begin{tabular}{|c|c|c|c|c|c|c|c|}
\hline \multirow{3}{*}{ Season } & \multicolumn{3}{|c|}{ Cattle } & \multicolumn{4}{|c|}{ Buffaloes } \\
\hline & \multirow{2}{*}{$\begin{array}{c}\begin{array}{c}\text { Total } \\
\text { calvings }\end{array} \\
\end{array}$} & \multirow{2}{*}{$\begin{array}{l}\text { Abortion } \\
\text { No \% } \\
\end{array}$} & \multirow{2}{*}{$\begin{array}{l}\text { Stillbirth } \\
\text { No } \% \\
\end{array}$} & \multirow{2}{*}{$\begin{array}{c}\begin{array}{c}\text { Total } \\
\text { calvaings }\end{array} \\
\end{array}$} & \multirow{2}{*}{\multicolumn{2}{|c|}{$\begin{array}{l}\text { Abortion } \\
\text { No } \%\end{array}$}} & \multirow{2}{*}{$\begin{array}{l}\text { Stillbirth } \\
\text { No } \% \\
\end{array}$} \\
\hline & & & & & & & \\
\hline Autumn & $26(35.15 \%)$ & - & 19.23 & $44(38.59 \%)$ & - & $=$ & 4.54 \\
\hline Winter & $15(20.27 \%)$ & - & & $33(28.94 \%)$ & 2 & 6.6 & 3.03 \\
\hline Spring & $23(31.08 \%)$ & - & & $19(16.66 \%)$ & - & - & \\
\hline Summer & $10(13.51 \%)$ & - & 30 & $18(15.78 \%)$ & 1 & 5.55 & 11.11 \\
\hline Total & 7.4 & - & 10.81 & 114 & 3 & 2.63 & 4.38 \\
\hline
\end{tabular}

Table (4) :- Incidence of abortion and stillbirth among different parities in cattle and buffaloes.

\begin{tabular}{||c|c|c|c|c|c|c||}
\hline \multirow{2}{*}{$\begin{array}{c}\text { Dam } \\
\text { parity }\end{array}$} & \multicolumn{3}{|c|}{ Cattle } & \multicolumn{3}{c|}{ Buffalo } \\
\cline { 2 - 7 } & $\begin{array}{c}\text { Total } \\
\text { calvings }\end{array}$ & Abortion & Stillbirth & $\begin{array}{c}\text { Total } \\
\text { calvings }\end{array}$ & Abortion & Stillbirth \\
\hline First parity & 21 & $\ldots--$ & $3(14.29 \%)$ & 24 & $1(4.16 \%)$ & $1(4.16 \%)$ \\
\hline Second parity & 20 & $\ldots-$. & $3(15.00 \%)$ & 27 & $1(3.70 \%)$ & $2(7.41 \%)$ \\
\hline Third parity & 33 & $\ldots \ldots$ & $2(6.06 \%)$ & 63 & $1(1.59 \%)$ & $2(3.18 \%)$ \\
\hline
\end{tabular}

Table (5):- Abortion and stillbirth in relation to calving performance in cattle and buffaloes :

\begin{tabular}{|c|c|c|c|c|c|c|}
\hline \multirow{2}{*}{$\begin{array}{c}\text { Reproductive } \\
\text { Status }\end{array}$} & \multicolumn{3}{|c|}{ Cattle } & \multicolumn{3}{|c|}{ Buffalo } \\
\cline { 2 - 7 } & $\begin{array}{c}\text { Assisted } \\
\text { Calvings }\end{array}$ & $\begin{array}{c}\text { Unassisted } \\
\text { Calvings }\end{array}$ & Total & $\begin{array}{c}\text { Assisted } \\
\text { Calvings }\end{array}$ & $\begin{array}{c}\text { Unassisted } \\
\text { Calvings }\end{array}$ & Total \\
\hline Abortion & -- & -- & -- & $1(33.33 \%)$ & $2(66.67 \%)$ & 3 \\
Still birth & $3(37.5 \%)$ & $5(62.5 \%)$ & 8 & $1(20.00 \%)$ & $4(80.00 \%)$ & 5 \\
\hline
\end{tabular}


Table (6) : Average calf weight, expulsion time, number of cotyledons and placental weight in cattle and buffaloes.

\begin{tabular}{|l|c|c|c|c|}
\hline \multirow{2}{*}{\multicolumn{1}{|c|}{ Items }} & \multicolumn{2}{c|}{ Cattle } & \multicolumn{2}{c|}{ Buffalo } \\
\cline { 2 - 5 } & Stillbirth & Control & Stillbirth & Control \\
\hline No. of observations & 8 & 10 & 5 & 10 \\
Calf weight (Kg) & $24.5 \pm 4.6$ & $28.8 \pm 7.5$ & $37.1 \pm 8.14$ & $40.12 \pm 7.19$ \\
Expulsion time (hours) & $4.9 \pm 0.89$ & $3.7 \pm 1.9$ & $3.6 \pm 1.67$ & $4.9 \pm 1.55$ \\
Weight of placenta (Kg) & $2.4 \pm 0.82^{\mathrm{c}}$ & $4.4 \pm 1.14^{\mathrm{d}}$ & $4.8 \pm 1.08$ & $6.3 \pm 1.9$ \\
No. Of cotyledons & $83.6 \pm 23$ & $88.3 \pm 7.9$ & $105.6 \pm 25.6$ & $106.7 \pm 13.4$ \\
\hline
\end{tabular}

*. Different superscripts c,d mean significant differences $(\mathrm{P}<0.05)$.

Table (7) : Blood Picture associated with late abortion in buffaloes.

\begin{tabular}{|l|c|c|c|}
\hline \multirow{2}{*}{ Parameters } & \multicolumn{2}{|c|}{ Buffalo } & \multirow{2}{*}{ Difference \% } \\
\cline { 2 - 3 } & Abortion & Control & \\
\hline $\mathrm{PCV} \%$ & $30.6 \pm 2.30$ & $33.5 \pm 2.16$ & $-8.66 \%$ \\
$\mathrm{Hb} \mathrm{gm} / \mathrm{dL}$ & $12.03 \pm 0.15$ & $12.3 \pm 0.50$ & $-2.20 \%$ \\
$\mathrm{RBCS} \times 10^{6} / \mu \mathrm{L}$ & $6.41 \pm 0.28$ & $7.13 \pm 0.46$ & $-10.10 \%$ \\
$\mathrm{WBCS} \times 10^{3} / \mu \mathrm{L}$ & $5.8 \pm 0.26^{\mathrm{c}}$ & $4.4 \pm 0.83^{\mathrm{d}}$ & $31.82 \%$ \\
$\mathrm{MCV} \mathrm{FL}$ & $47.73 \pm 5.29$ & $46.98 \pm 3.53$ & $1.60 \%$ \\
$\mathrm{MCHC} \%$ & $39.31 \pm 2.98$ & $36.71 \pm 3.99$ & $7.08 \%$ \\
$\mathrm{MCH} \mathrm{Pg}$ & $18.76 \pm 1.15$ & $17.25 \pm 3.27$ & $8.75 \%$ \\
\hline
\end{tabular}

*. Different superscripts c,d mean significant differences. $(\mathrm{P}<0.05)$ 


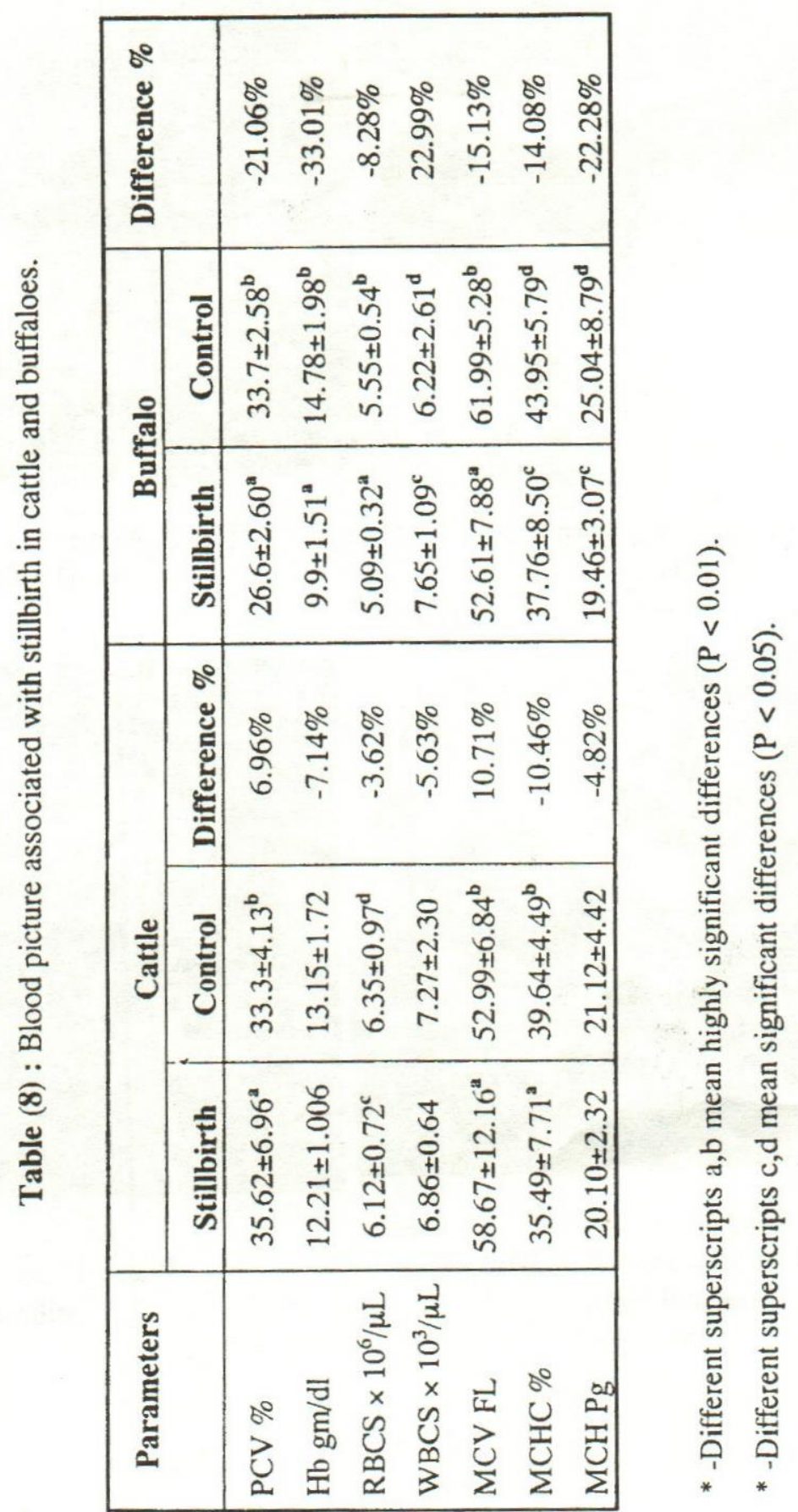




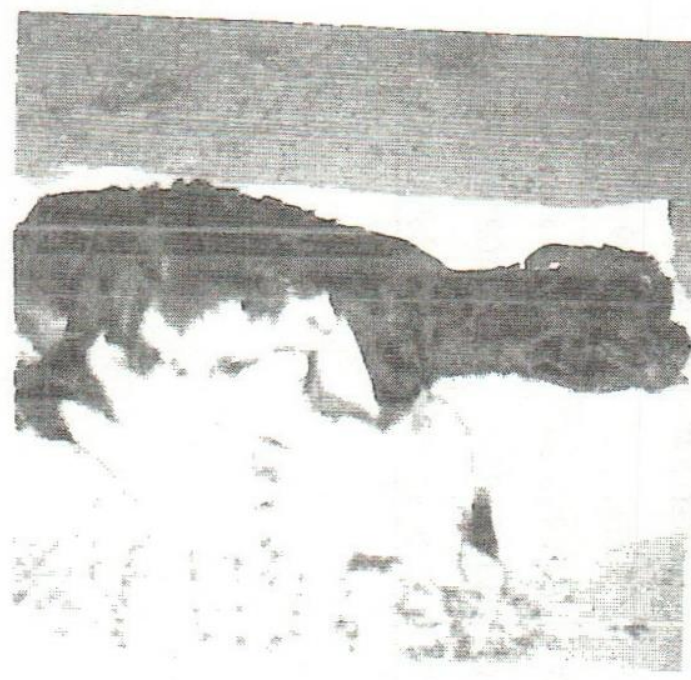

Fig 1: Anomalus stillborn calf (cattle)

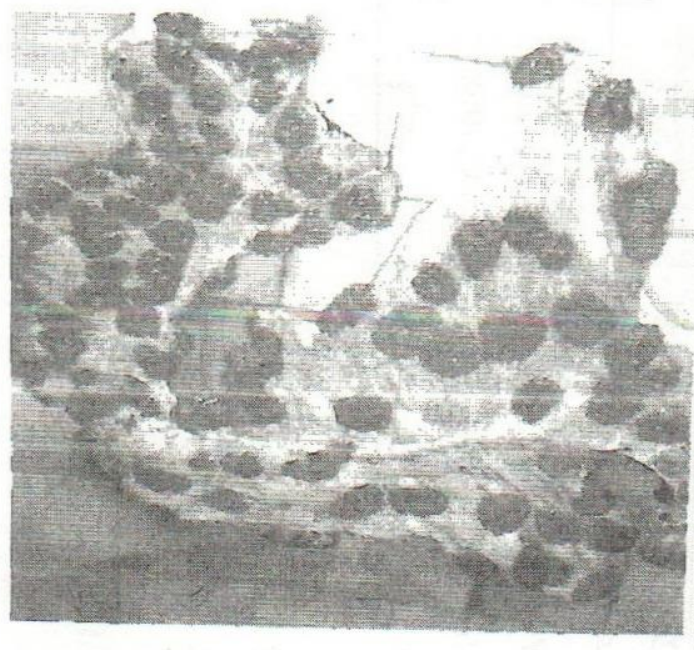

Fig.3: Placenta associated with normal birth.

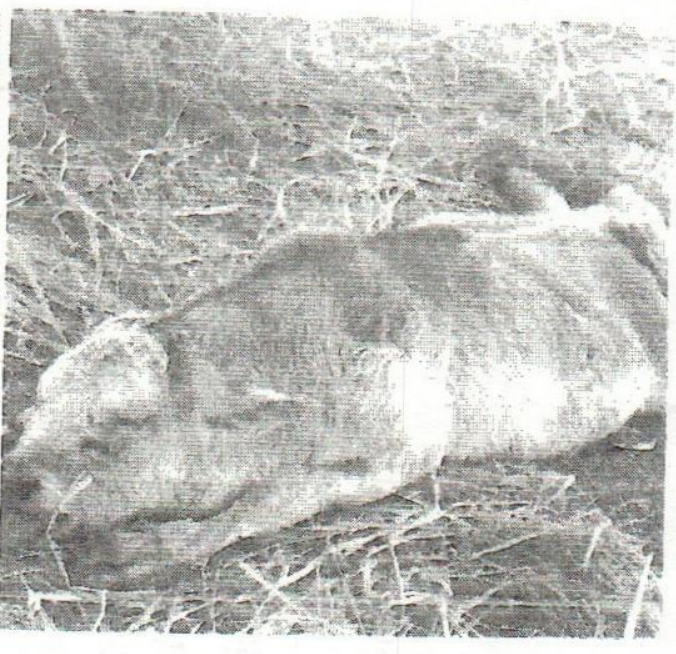

Fig 2: Anomalus stillborn calf (buffalo)

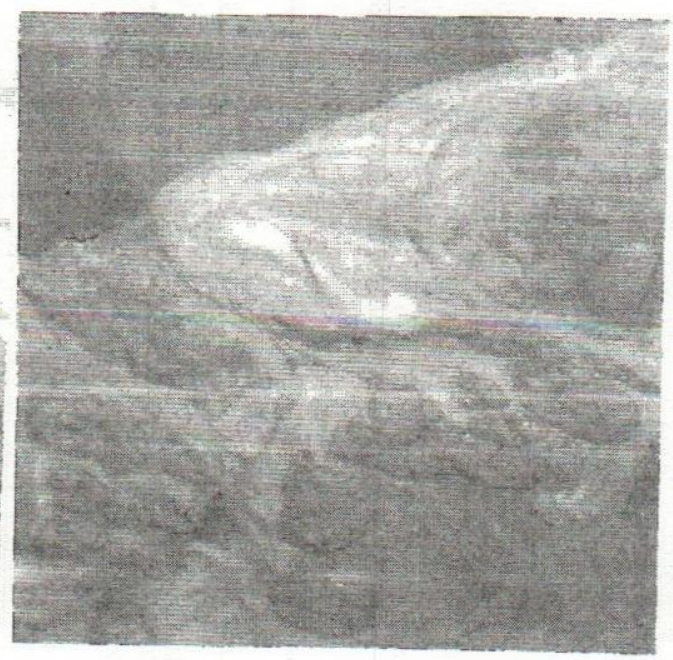

Fig 4: Placenta associated with stillbirth. 

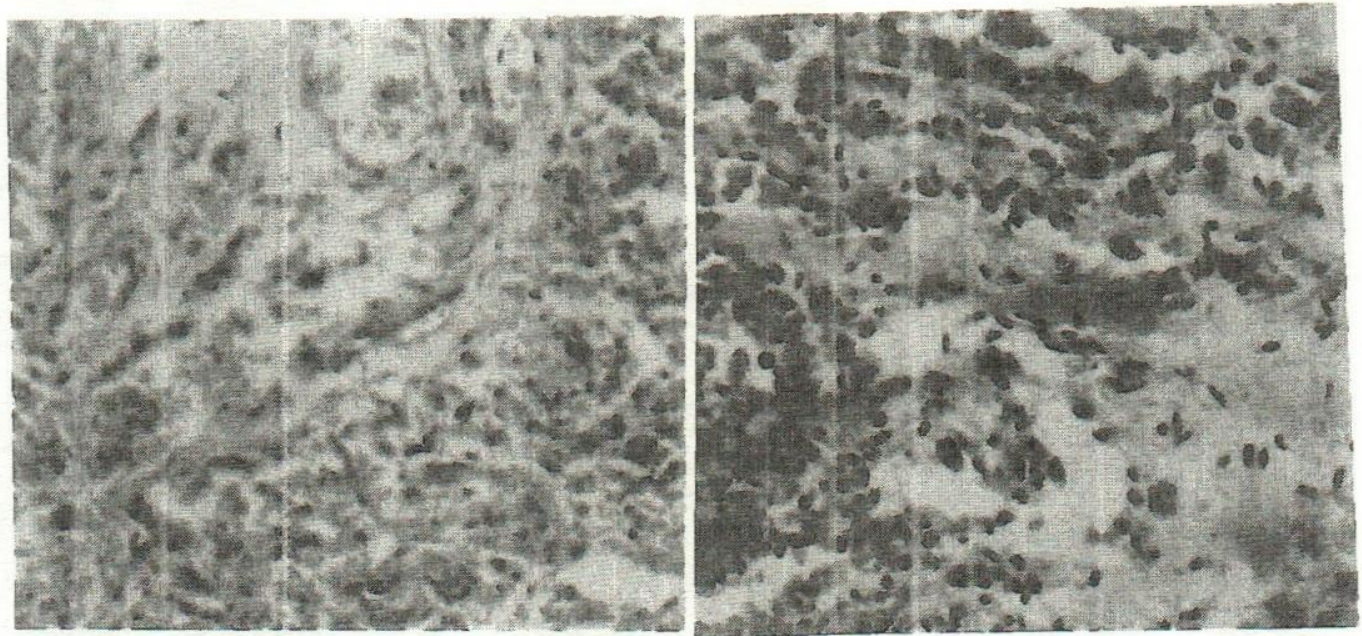

Fig 5: Placenta of normal caiving in tuffato Fig 6 . Placenta of nomal calving in cattle showing mild congestion, edema and mesenchymaicells. H\&F stain, $x 250$ showing focal placentitis. $\mathrm{H} \& \mathrm{E}$ stitin. $\times 250$
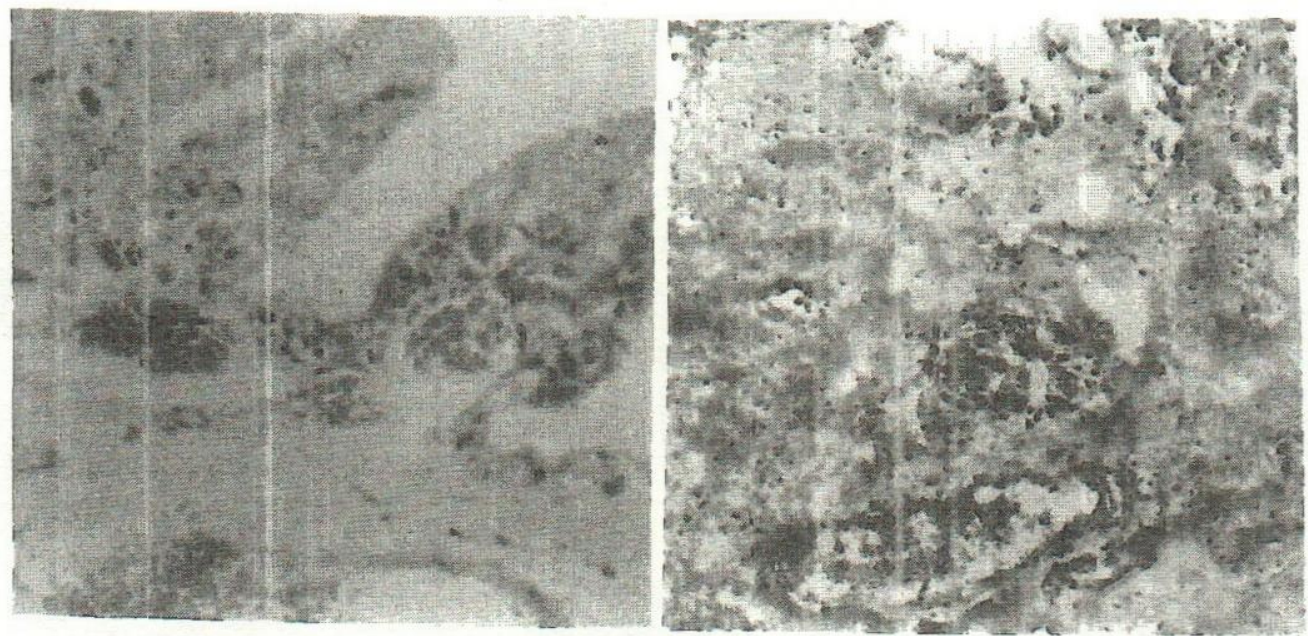

Fig 7 Placenta of ahorted buffalo showing necrotic epithelium, congestion and leukocytes H\&F stain, $\times 250$

Fig 8: Placenta of aborted buffalo showing hyalinization, congestion, edema and leukncytes. H\&E stain, $\times 100$ 


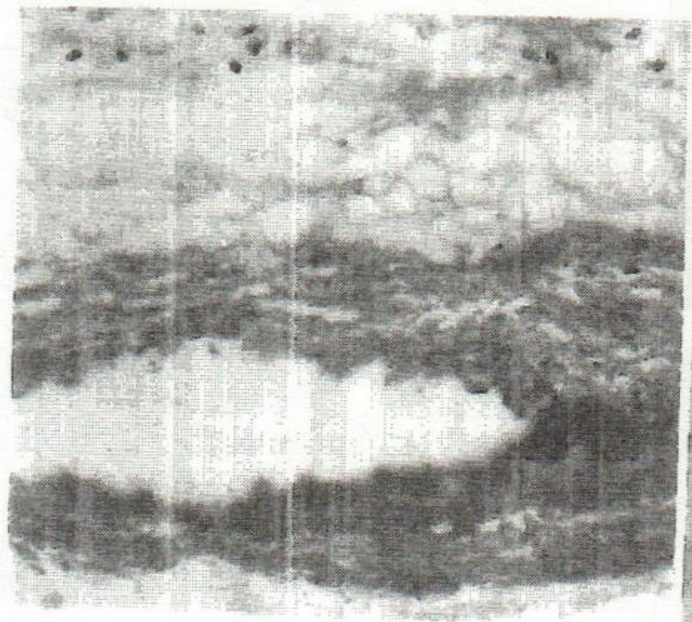

Fig. 9. Placenta of abonted bufralo showing necrotic endothelium and pervascular fibrosis. H\&E stain, x 400

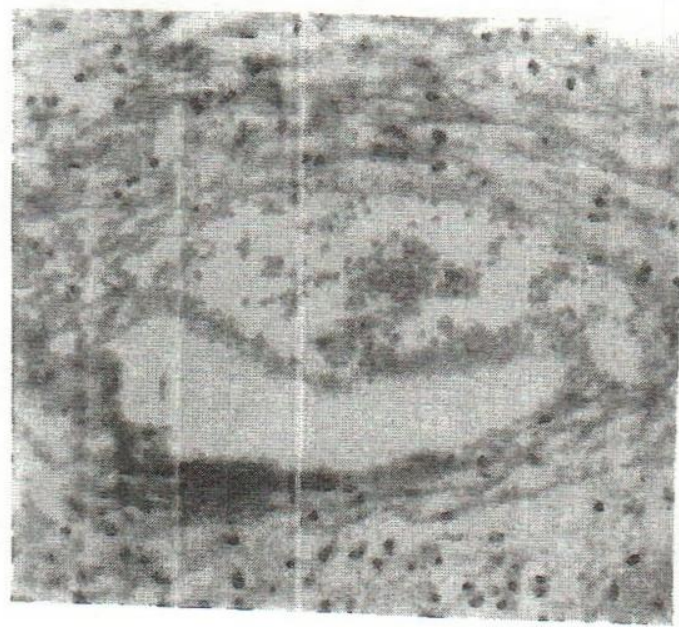

Fig 11. Placenta of stillbirth buffale showing necrotic and acuolated blood vessel wall H\&E stain, $\times 250$

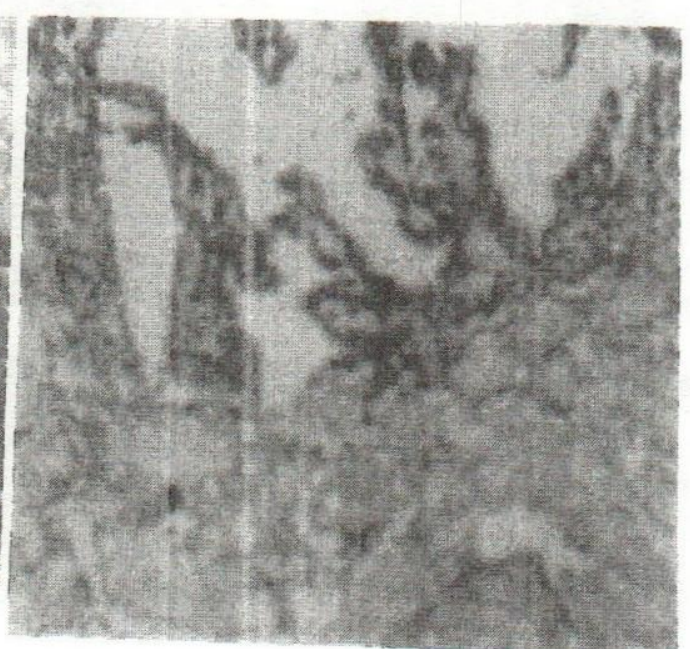

Fig 10. Placenti of stillbirth cattle showing necrotic truphoblasts with karryolytic miclei. H\&E stain, $\times 100$

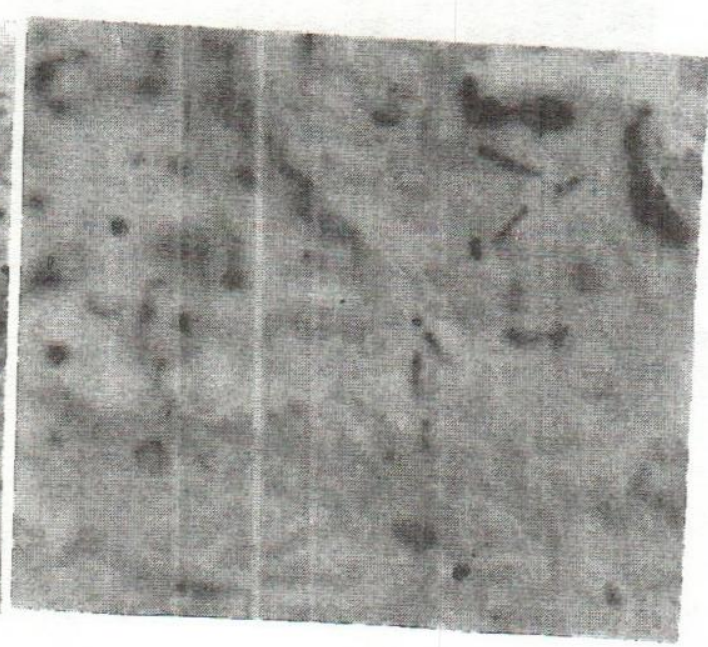

Fig 12. Placenta of normal calving showing Gram positive cocci and Gram negative bacilli. Brown \& Brenn stain, x1000 